\title{
Economic Empowerment for Poor Women Using Grameen Bank Model in Indonesia
}

\author{
Siti Inayatul Faizah ${ }^{1}$ and Uus Ahmad Husaeni ${ }^{2}$ \\ ${ }^{1}$ Universitas Airlangga \\ ${ }^{2}$ Universitas Suryakancana
}

\section{Abstract}

This research aimed at analysing the contribution of Islamic Microfinance which used Grameen Bank model to the economic empowerment and poverty alleviation in Cianjur Regency. This research used quantitative approach. Primary data were collected using questionnaires. While the secondary data were derived from the annual report of the cooperative, Central Bureau of Statistics of Cianjur, journals and other related literature. The sampling technique used was purposive sampling. The number of samples used was 100 female poor respondents from all female members of Cooperative Dhuafa Mitra in 2017, at Mande branch office, Cianjur Regency. The analytical technique used was Spearman correlation, and Kruskal-Wallis free sample test. This research concluded

Received: 10 February 2019

Accepted: 14 March 2019

Published: 28 March 2019

Publishing services provided by Knowledge E

(c) Siti Inayatul Faizah and Uus Ahmad Husaeni. This article is distributed under the terms of the Creative Commons

Attribution License, which permits unrestricted use and redistribution provided that the original author and source are credited.

Selection and Peer-review under the responsibility of the ICIEBP Conference Committee. that Islamic Microfinance using Grameen Bank model had positive contribution to economic empowerment of poor women. Financial capital and social capital were the keys to success in empowering the poor community. Islamic microfinance using Grameen model also had a significant relationship with poverty alleviation. This article also proved that poverty could be overcome if economic development is run based on human development. The results of this study strengthen the conclusions of Nasim Shah Shirazi and Aman Ullah Khan (2009), Rajesh Kumar Shastri (2009), Muhammad Yunus (2008), Jahangir Alam Chowdhury (2008), Mohammad Anwarul Kabir, Suman Dey and Mohammad Shamsal Islam (2012) Sadegh Bakhtiari (2006), as well as Musa bin Mansour and Tawfiq Brahm Chaouch (2013) who stated that micro-loans are able to create self-employment opportunities and have an impact on rural poverty reduction and unemployment. The results of this study are different from the conclusions of JUJ Onwumere (2012), Anis Chowdhury (2009), Dan Matovu (2006) and Katsushi S. Imai (2010) which stated that microfinance just increases human capital, creates black spots and negatively impacts Women empowerment.

Keywords: Grameen Bank, Poverty, Economic Empowerment, Spearman correlation, and Kruskal-Wallis.

\section{Introduction}

The biggest problem of economics is the problem of poverty. Poverty is multidimensional because it includes social, cultural, and even religious aspects (Muhammad, 2011). Poverty is the main problem that plagues Indonesia. Poverty is something that is created and forced to someone from the outside (Euis, 2009). Therefore, poverty can 
be eliminated. The necessary effort to make the poor free of poverty is by creating an environment for them to develop well. When the poor are able to take advantage of their energy and creativity, the poverty will disappear (Muhammad and Karl, 2011).

Complex poverty problems require joint and coordinated intervention of all parties. Over the years, the handling has tended to be partially and unsustainable. Therefore, systemic and comprehensive changes are required in the effort to reduce poverty since it can endanger belief and morals (Mudrajad, 2013). The poor can commit criminality because of an urgent stomach needs.

According to Euis Amalia (2009) one of the efforts to reduce poverty is by cutting off the poverty chain through empowering micro-enterprises and providing capital assistance. Capital loans for micro-enterprises are another form of social business that can eradicate poverty. Provision of Microfinance for the poor means that they can create their own jobs through self-employment. Microfinance should be allocated with the aim of helping to realize social benefits in general as the source of funds of Microfinance is publicly owned (Umer, 1985).

Opening employment means turning the unemployed people to be productive economic actors who can contribute their productivity (economic added value) to GNP (Gross National Product) (Sri, 2010). The effort to eradicate poverty through micro-loans and by focusing on micro-enterprises have several reasons; micro-enterprises are part of the poor who have productive willingness and ability and, nationally, their portion is more than $90 \%$ compared to large-scale enterprises. In addition, micro-loans and microenterprises can absorb large labours where many women are empowered through this sector. Moreover, micro-enterprises can support the national economy ( $>50 \%$ of national GDP) (Euis, 2009).

It has been more than 20 years since Indonesia had a Ministry of Cooperatives and Small and Medium Enterprises (CSMEs), supported by the obligations of banks to set aside $20 \%$ of total credit for MSMEs, and the obligation of SOEs to set aside some of their profits for the development of MSMEs. But this has not been met, because banks prefer to channel credits for consumption activities. Finally, MSMEs remain undeveloped. Poverty and unemployment seem to be eternal (Muhammad and Alan, 2010). In Bangladesh, since 1983, Muhammad Yunus has been pioneered the microcredit program and founded Grameen Bank. Grameen Bank is an institution specially designed for the capital provided for the poor. The Grameen system is an alternative solution for the poor not to become victims of the coveted loan sharks.

Long before Muhammad Yunus succeeded in alleviating poverty in Bangladesh with Grameen Bank and winning the Nobel Peace Prize in 2006, Amartya Sen had first 
undertaken a research on the causes of hunger, social imbalances, and poverty. The results of such research were written in 'Poverty and Famines: An Essay on Entitlement and Deprivation' published by Oxford University Press in 1981, then Amartya Sen was awarded the Nobel Prize in Economics in 1998. This book influenced many international organizations and world countries in handling the food crises. Through the capability approach, Amartya Sen said that the main dimension in overcoming social imbalances and eradicating poverty were the enhancement of the individual's capacity, access to health and education, and increased income (Irwan, 2008).

One effort to improve the ability of the poor is by providing opportunity to work and access to capital. In line with Sen's research, Rajesh Kumar Shastri (2009) stated that capital provided for micro-enterprises through Microfinance is an effective tool for eradicating poverty and impacting the national economic and social aspects significantly. Muhammad Kashif Khan Durrani (2011), added that micro-capital is a very helpful tool to gain prosperity and improve the poor's social standards. This shows that Amartya Sen's theory of capability has been approved by Shastri and Durrani's research results, that improving individual capacity in eradicating poverty can be pursued by providing venture capital and allowing the poor to work.

Imam Al-Syaibani $(234 \mathrm{H})$, one of the pioneers of the science of Islamic Economics, asserted that a needy person needs the rich one while the rich person needs the power of the poor. From that mutual-help, the distribution of works and benefits will be evenly distributed. In line with Imam Al-Syaibani, Abu Ubaid (222 H) emphasized on justice. Implementation of the principle of justice leads to economic and social prosperities (Ridjaluddin, 2007). Umer Chapra (2001) clearly stated that the teachings of Islamic economics were not only limited to be normative but also capable to solve human problems, such as poverty.

In Bangladesh, Yunus and Grameen Bank were able to organize communities to fight against poverty. Yunus with the poor was able to apply modern management and successfully built Bangladesh. As many as 97 percent who were given micro-loans and working in the MSME sector were women (Euis Amalia, 2009).

The success of Yunus's microfinance program in Bangladesh raised the expectation that the Grameen Bank microcredit method could be applied almost universally. Between the late 1980s and early 1990s, Jonah proved that Grameen idea could improve the life level of poor people around the world. Grameen attracted people whose potentials to replicate this micro-lending program ini (Muhammad and Alan, 2010). Replication in Malaysia and Philippines have reaped a smooth path, and now in Indonesia there are microfinance institutions using the system of Grameen Bank. 
One of the microfinance institutions that use Grameen Bank system in Indonesia is Mitra Dhuafa Cooperative established in 2005. This cooperative which operated with Grameen Bank system has had 212,607 members and 96 branch offices throughout Indonesia, per July 2016. Like Grameen Bank, the cooperative that has the slogan "We Care the Poorest Women" is focusing on poor women. Total outstanding of Mitra Dhuafa, until July 2016, has reached 212,964 billion Rupiahs. Mitra Dhuafa Cooperative which becomes the research site is Mitra Dhuafa of Mande branch office, in Cianjur Regency.

Cianjur Regency is the preferred place for research because, demographically, the number of female population, in 2013 , was $1,088,727$ people and the poverty rate in Cianjur Regency reached 267,887 people. In addition, the most population of Cianjur Regency were educated in elementary level/equal, that is, as many as 577,195 inhabitants. While infant mortality rate in Cianjur was quite high, increasing from 14.16 per thousand live births in year 2013 to 16.14 per thousand live births in 2014 .

Mitra Dhuafa Cooperative uses Grameen Bank system because in micro-loan distribution it focuses on poor women, makes them in small groups, running group gathering regularly and using joint liability system, without any collateral. Cooperative management has met and studied directly to Muhammad Yunus in Bangladesh. The cooperative unites small economic and social forces into a great power. It comes up to help individuals to be independent together. The independence is a manifestation of selfempowerment activities. Therefore, the contribution of microfinance channelled by Mitra Dhuafa Cooperative with Grameen Bank system to economic empowerment of poor women in Cianjur Regency to be free from poverty is very interesting to be studied and worthy to be studied further.

\section{Method}

\subsection{Population}

Population is a group of people, events or everything having certain characteristics (Ety, 2009). Population in this study was low-income women, members of Cooperative Mitra Dhuafa in its Mande branch office, Cianjur Regency. The population was taken from a number of members of the cooperative in 2016. Cooperative Mitra Dhuafa was chosen because it was one of micro finance institutions as Grameen replicas in Indonesia. Meanwhile, the number of samples in this study was the respondents who were members of Mitra Dhuafa Cooperative. According to Hendri Tanjung dan Abrista Devi (2013) a correlational study takes at least 30 samples to test whether or not the 
relationship exists. Mudrajad Kuncoro (2009) added, if the number of samples is more than 30 respondents, the test results will be better and more precise.

\subsection{Validity and reliability}

A good instrument is an instrument that measures what is designed to be measured as accurately as possible (Agus, 2007). For that, a test for the instrument is required before use. The next step is to do the Validity Test. The Validity Test indicates the extent to which a measuring instrument measures what it wants to measure. The arranged questionnaire should measure what it wants to measure. Thus, validity refers to the accuracy and precision of the test in carrying out its measurement functions. The technique used for the validity test was by calculating the correlation between each statement and the total score, using the model of Product Moment correlation technique (Singgih, 2012).

In the next stage, Reliability test was used. Reliability test is an index that indicates the extent to which a measuring device can be trusted or reliable. Reliability shows the consistency of a measuring device in measuring the same symptoms (Cyrus and Nitin, 2010). According to Kaplan and Saccuzzo (1993), reliability coefficients ranging between 0.70-0.80 are considered good for use. Reliability test was done by Cronbach Alpha technique, the most common coefficient used to evaluate internal consistency since it describes the variation of the items.

\subsection{Data analytical technique}

Data analytical technique used in this research was Spearman's Correlation Test. Spearman's correlation coefficient is a measure of whether or not a link between two variables is important. The test was performed to determine whether there was a statistical correlation or not (Masri and Sofian, 2008). Spearman's correlation test is a nonparametric test used for data with ordinal type (having a sequence, such as like, quite like and dislike). Based on Guilford's (1956) criterion, a good item is one that has a correlation coefficient above 0.20 .

Kruskal-Wallis test was then performed. Kruskal-Wallis test aims to test two free samples with ordinal or nominal type data. The purpose of testing was to find out whether the two samples were the same or different. If the Kruskal-Wallis test results have a significance value less than 0.05 , both samples are equal, and if the value of 
significance is greater than 0.05, the two samples are different (Singgih, 2012). KruskalWallis is a very popular nonparametric test for comparing independent sample $\mathrm{K}$, which has results stronger than the median test's results.

\section{Results and Discussion}

The empowerment instrument used by Mitra Dhuafa Cooperative is Islamic micro financing. The financing program uses Grameen Bank pattern. It aims to make poor women in rural areas out of poverty line. Amartya Sen (1983) asserted that poverty should be measured in the space of ability or capability and not merely measured by the size of one's income (income poverty). Poverty is a multidimensional problem. To that end, this study seeks to see poverty of various dimensions, whether from economic, health, and education adequacy. This study measures poverty in a capability approach of cooperative members.

\subsection{Micro financing, capability level, and poverty rate of Mitra Dhuafa cooperative members}

\subsubsection{Level of sharia micro financing usage}

Many studies have shown that microcredit has a positive effect and contributes significantly to poverty alleviation. The results of Clement Abur and Terande Torruam (2012) concluded that micro loans affect the poverty status of respondents and microfinance institutions are able to solve various problems and have helped reduce the poverty level of respondents. According to Bakhtiari (2006), microcredit can be an effective tool for alleviating poverty compared to other poverty alleviation programs. However, because poverty is a multidimensional and complex problem, the distribution and utilization must be careful in order to achieve the goal of poverty alleviation.

This section explains the general picture of microfinance and its utilization by poor women members of the cooperative, their level of capability, and the level of poverty experienced by cooperative members. Microfinance is not limited to the amount of rupiah lent to the poor to run micro businesses. Moreover, microfinance includes how loans are used and benefits, the convenience offered the increase in savings and income, and success in economic empowerment. This is in accordance with the statement of Anwarul Kabir, Suman Dey and Shamsal Islam (2012); Sadegh Bakhtiari (2006). 
Furthermore, to know the picture of Islamic microfinance patterned Grameen Bank in general, can be seen in the following Table:

TABLE 1: DESCRIPTION OF ISLAMIC MICROFINANCE.

Score
$64-73$
$55-63$
$46-54$
Amount
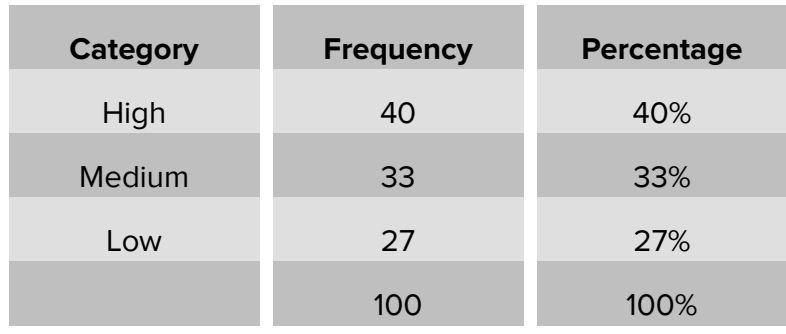

Based on Table 1 above, it is known that 33 members of the cooperative get micro financing and benefit from such financing at a moderate level, and as many as 40 people at a high level. This can happen because access to micro finance provided by Mitra Dhuafa Cooperative to its members through a simple procedure, easy, and not just in the form of nominal rupiah. In microfinance, however, there are social capital and the advantages provided by the cooperative to its members, namely micro-business assistance, joint liability system, not requiring physical collateral, providing educational funding, and life insurance financing.

The first advantage possessed by microfinance with Grameen Bank pattern on Mitra Dhuafa Cooperative is the existence of assistance and monitoring of micro business by the cooperative to each member. The second advantage is that at weekly meetings basically not only to fulfill the obligation to pay installments and save. In weekly meetings are also used to discuss the problems encountered during running a micro business. The Mitra Dhuafa Partner's field staff help to find solutions, even if there is still time to spare before the next center, a staff takes time to visit members' houses and see how their micro business is developing. The microfinance channeled by Mitra Dhuafa Cooperatives is specifically for poor women, where they have no valuable items that can be used as collateral. In accordance with the opinion of Maria Nowak (2008) that the difference between micro loans and conventional credit is on new targets, the poor and the rejected.

The poor and the rejected to obtain banking services and other financial institutions because they are unbankable, have no collateral. To this end, microfinance with the Grameen Bank pattern is based on a belief in the borrower's ability to achieve prosperity. In order to reduce the risk of non-performing financing, Grameen's micro-financing uses a joint liability system.

According to Mark Schreiner (2003), joint liability is a policy in which if a member of the group performs a default may cause a loss of access to micro loans for all 
members within the group. Therefore, if there is a member who cannot afford to pay the instalment then the other member members must bear the instalment for a while. This joint liability system can also reduce the risks because joint responsibility gives members encouragement to ensure that their colleagues are not wasting their loans and encouraging their colleagues to avoid delinquent payments, even temporary bail unpaid loans. A joint liability is also useful for helping and helping the member who at the time of paying the instalment is not economically capable and not because he is negligent. For that, members who are able to provide bail first (deferral of loans that cannot afford) until the relevant able to return. The joint responsibility system is like the principle of Kâfalah in Islamic economics

Kâfalah is a guarantee provided by a third party that he will bear the repayment of the debtor's loan if the debtor cannot afford to pay off (due to bankruptcy or escape). In the joint responsibility system, kâfil (guarantor) is a fellow member in one group, while the ma'ful anhu is a member who cannot afford to pay weekly installments. Therefore, if a member cannot afford to pay the installment in a weekly assembly, then the other members of the group in the group jointly pays for the installment.

\subsubsection{Level of membership capability of Mitra Dhuafa cooperatives}

In relation to poverty, as Amartya Sen (1983) argues, that poverty and hunger are not caused by food shortages, but because of inadequate capabilities and opportunities. Those who fall into poverty are caused by the inability to prosper. Many factors that cause a person do not have the ability and opportunity to achieve welfare, such as level of education and health. The cost of children's education and the cost of health is very expensive cannot be reached by the poor. Amartya Sen (1983) asserted that the enhancement of individual capabilities of the poor through access to education, access to health and respect for human rights, is a key dimension in overcoming social imbalances and eradicating poverty. Description of capability level of members of Mitra Dhuafa Cooperative can be seen in the following Table:

TABLE 2: LEVEL OF MEMBERSHIP CAPABILITY OF MITRA DHUAFA COOPERATIVES.

\begin{tabular}{|c|c|}
\hline Score & Category \\
\hline $57-67$ & High \\
\hline $47-56$ & Medium \\
\hline $35-46$ & Law \\
\hline
\end{tabular}

\begin{tabular}{|c|}
\hline Frequency \\
\hline 15 \\
\hline 67 \\
\hline 18 \\
\hline 100 \\
\hline
\end{tabular}

\section{Percentage}

$16 \%$

$60 \%$

$24 \%$ $100 \%$ 
Based on Table 2 above found that the majority of members of the cooperative (frequency of 67 people) have a level of capability in the medium category. This means that most respondents have a pretty good level of capability. This happens because the key to improving the poor's capacity is to respect the rights of the poor and give them equal opportunities to develop their individual potentials. The poor are also human beings, so the environment in which they live should give them the opportunity to get a decent education and access to health, as upper-middle class people can freely obtain. Therefore, Mitra Dhuafa Cooperative gives opportunity to poor woman to get access financing for micro business. Starting from this access is expected to be a stepping stone to further their ability to get education and access to health. A total of 67 respondents have a moderate level of capability in table 5.2, illustrating that the struggle of Mitra Dhuafa Cooperative not in vain. Medium categories mean has increased from low category, because members of cooperatives who become respondents have at least 1 year get micro financing and run micro business. The effort of Mitra Dhuafa Cooperatives to empower poor women through microfinance services is a very good thing. This shows that women who previously only stayed at home and resigned to the economic crush, now they are working to be able to fight along with her husband to prosper the family.

Microfinance is a financial capital or economic capital for poor women. The advantages that exist in Mitra Dhuafa Cooperatives with Grameen Bank pattern that member also get social capital. Therefore, Mitra Dhuafa Cooperatives has financial products and social products. Some social products include self-reliance, discipline, and responsibility. Social capital is something of value to poor women in remote villages because it makes them have bargaining power, dared to voice what they want. While independent is a major part of empowerment. Empowerment process aims to create independence, not dependency. If they are independent, the poor do not depend on anyone and in any form of assistance. This is in line with Maria Nowak's (2008) assertion that the salvation of the poor does not lie in the hands of the rich who founded various charities and charities. Therefore, independence is very important for the poor to get out of poverty. Someone who does not have enough capability and then he will have difficulty to be fully independent. While the capability itself comes from the opportunity given to the poor to develop its potential. One way is to provide microfinance loans and provide opportunities for the poor to cultivate micro-enterprises.

The three main things that benchmark a person's level of capability are education, health, and income. Although there are other things that are still debated in setting parameters of this level of capability. However, the three main things that have 
been contained in the Human Development Index. Of these three, the most important component is education. As written by Kemal Aziz Stamboel (2012), that capability approach imposed by Amartya Sen emphasizes the intrinsic value of education that is an opportunity, entitlement, and ways to improve the quality of life. With education, one will get more opportunities and wider choices. Through education also one can determine the right choices, the choices that can improve the level of welfare.

In line with what was written by Stamboel mentioned above, Mitra Dhuafa Cooperative also showed its concern for the education of children of mothers who are members of cooperatives. The co-operative party provides education funding to children to university. As for children who have graduated from high school can work in cooperatives. Through education, children are expected not to inherit the poverty suffered by their parents. With higher education, they later have the ability to compete in the world of work and the ability to reach a more prosperous future. As for their mothers (poor women members of cooperatives) who are illiterate, given lessons on how to write and read by field staff Mitra Dhuafa Cooperative. At least each member can write a name and a signature.

\subsubsection{Poverty rate of Mitra Dhuafa cooperative members}

Indicators for measuring poverty and welfare commonly used by the state are national income and per capita income, which should not be used anymore. Kemal Aziz Stamboel (2012), states that per capita income is nothing but the result of the total national income on the population. It encourages countries to increase their production to be considered a prosperous country. It is in this process that man is considered a factor of production, equated with machinery, soil, sand, gravel, and other factors of production. It is not humanizing at all. In Indonesia, the government's approach to poverty alleviation has tended to be the view that poverty is a matter of low per capita income or just looking at income poverty, irrespective of the fact that poverty is a multidimensional problem. This resulted in the policy being implemented is oriented towards the provision of cash assistance, either for poor families or poor villages.

The cash assistance is contained in the government's three poverty alleviation program. Unconsciously cash assistance has led to the dependence of the poor on the mercy of the government and others. The poor need more jobs. If there are no jobs to share, then the poor should be empowered to be able to open their own jobs. Microfinance is an important empowerment tool for women. They can be independent 
and ultimately can help themselves to get out of the cycle of poverty. Poverty level of cooperative members can be seen in the following Table:

TABLE 3: POVERTY RATE OF MITRA DHUAFA COOPERATIVE MEMBERS.

\begin{tabular}{|c|c|}
\hline Score & Category \\
\hline 63-71 & High \\
\hline $54-62$ & Medium \\
\hline $45-53$ & Law \\
\hline
\end{tabular}

\begin{tabular}{|c|}
\hline Frequency \\
\hline 22 \\
58 \\
20 \\
100 \\
\hline
\end{tabular}

\begin{tabular}{|c|}
\hline Percentage \\
\hline $22 \%$ \\
\hline $58 \%$ \\
\hline $20 \%$ \\
\hline $100 \%$ \\
\hline
\end{tabular}

Based on Table 3, it was found that most of the poverty level of cooperative members was in moderate category, with the number of frequencies as many as 58 people and then followed by low category level that is 20 people. This means that the struggle of Mitra Dhuafa Cooperative in the prosperity of its members, who are all poor women, began to see the result. All respondents have been a minimum member of the cooperative for 1 year, so have begun to power and feel the benefits obtained from micro financing. This happens because the efforts that have been made by cooperatives in improving the welfare of poor households through the empowerment of women has made poor women slowly rise from helplessness.

The Mitra Dhuafa cooperative seeks to create an environment where poor women live, allowing for growth and prosperity. Microfinance is not a panacea that can cure poverty in the blink of an eye. Microfinance also does not solve all development problems, but as Maria Nowak (2008) notes, microfinance has moved global knowledge and productivity, factors of production, infrastructure, water and land, health and education. It is more important to do than on large projects that are not adapted to the environment. Through microfinance, in addition to the equality of production factors, equality of opportunity to achieve a prosperous life is also accomplished.

For poor people, microfinance should be made as simple as possible in the aspects of procedures and liquefaction processes. For that reason, enough withdrawal with the husband's consent and no need for collateral. In addition, during weekly gatherings, there are always small discussions related to the development of micro business and the economic condition of their families. They feel happy if the sounds and complaints are heard and helped to find a solution. Small things like this contribute to the success of the empowerment process. Not necessarily it is owned by other microfinance institutions, even banks even do not want to listen to the voices of the poor. The Mitra Dhuafa Cooperative really positions itself as a partner for the poor or marginalized and denied by banking services. 
According to Dan Matovu (2006) and Robert Chambers (2011), people who are isolated from various developmental accesses and fall into this powerlessness are another form and another dimension of poverty. This means that what is done by Mitra Dhuafa Cooperative by reaching the marginalized people to the countryside is very appropriate. Giving them access to micro-loans can make them feel valued and upheld by their dignity as human beings. When the poor feel humanized, they feel happy and energized to fight poverty.

\subsection{Relationship of micro financing and capability level of cooperative members with poverty alleviation}

\subsubsection{Relationship of micro financing with poverty alleviation}

Microfinance initiated by Mitra Dhuafa Cooperative has indicators adjusted to Grameen Bank pattern. Therefore, three main indicators are distribution process, micro business development and non-financial product. Grameen Bank patterned loans mean that microfinance uses patterns as used by Grameen Bank, which are group formation, attend weekly meetings, pay weekly installments and savings, and use a joint liability system. The development of micro business means that the cooperative has special attention to the continuity of the business run by members. This is, among other things, realized by business monitoring.

In addition to loans, this Grameen-style cooperative also has a non-financial product as owned by Grameen Bank in Bangladesh. Some non-financial products provided by the cooperative to its members are discipline, independence, increased bargaining power and awareness of the importance of education. According to Mark Schreiner (2003), in his dissertation stated that the most important non-financial service of the Grameen Bank system is social intermediation, which is creating social capital for poor women as a by-product of weekly meetings.

The Mitra Dhuafa Cooperative has tried to provide social capital. Poor women, who previously had no "place" in the social sphere, and even in the eyes of their husbands, are now daring to discuss with her husband to express her opinions and wishes and seek approval from her to be allowed to join the microfinance program. The poor women of cooperative members today have dared to decide to run a micro business for a more prosperous future. Grameen Bank patterned micro financing relationship with poverty level of cooperative members can be seen from Spearman correlation test as follows: 
TABLE 4: SPEARMAN TEST RESULT OF MICRO FINANCING VARIABLE WITH VARIABLE OF POVERTY ALLEVIATION, CORRELATIONS.

\begin{tabular}{|l|c|c|c|c|}
\hline \multirow{2}{*}{ Spearman's Rho } & & MicroFinancing & PovertyAlleviation \\
\cline { 3 - 5 } & MicroFinancing & Correlation & 1.000 & 0.268 \\
\hline & Coefficient & & \\
\hline & Sig. (2-tailed) & - & 100 \\
\hline & PovertyAlleviation & Correlation & $0.268^{* *}$ & 1.000 \\
\hline & Coefficient & & - \\
\hline & Sig. (2-tailed) & 0.007 & 100 \\
\hline
\end{tabular}

Based on Table 4, it can be seen that Spearman correlation test results show the result of 0.268 . That is, there is a micro-finance relationship with the level of poverty alleviation. This is in line with the facts on the ground that prove that microfinance is bringing substantial and tangible changes to empowering poor women in rural areas. Microfinance provides empowerment for women to gain a more prosperous life, by allowing them to take an active role in the development process and be the subject of development. As the subject of development, poor women play an active role in determining the future of children. The positive contribution of micro loans to poverty alleviation was also expressed by Nasim Shah Shirazi and Aman Ullah Khan (2009), from his research concluding that micro-loans in Pakistan have reduced national poverty by 3.07\%. The results are not large enough indeed, but if every year there continues to be a consistent reduction in the poverty rate, then most likely the dream of Muhammad Yunus to create a museum of poverty in the world will be achieved.

The positive relationship between microfinance and poverty alleviation of members of the Dhuafa Mitra Cooperative if consistently runs, there will be many poor, especially rural women who are empowered and out of poverty. With the same pattern of financing distribution and pattern of operation of cooperative institution, that is Grameen Bank pattern, so effort of poverty eradication in various branch of Cooperative Mitra Dhuafa spread one of them in Cianjur Regency start to show result.

After looking at the relationship between Grameen Bank micro financing and poverty alleviation, the results of the significance test are reviewed. The test results of significance of micro finance relationship with poverty alleviation in the above table can be seen from Approx value. Sig. ie 0.007. This means that the significance value of 0.007 is 
smaller than the alpha of $5 \%$ or $0.007<0.05$. Thus, it can be concluded that microfinance with Grameen pattern has a significant relationship with poverty alleviation. In line with this, Musa bin Mansour and Tawfiq Brahm Chaouch (2013) revealed that microfinance became one effective alternative to achieve development goals. These goals include poverty alleviation and eradication of unemployment. This is because microfinance has provided loan capital for micro and small enterprises, agriculture, and other small business ventures, particularly projects in rural areas. Which of these efforts has not been getting access to adequate capital services from various financial institutions. Cyprian Clement and Japheth Terande (2012) stated that the existence of microfinance institutions is able to make a real contribution in solving various problems in developing countries and has helped reduce the poverty level of its borrowers. In developing countries, where most of the poor live, require new breakthroughs to end poverty. For this purpose, the Mitra Dhuafa Cooperative is struggling to track villages to hold the hands of marginalized and rejected by banking services. Previously, the only financial access in the countryside was the loan shark. However, in reality, loan sharks cannot improve their welfare. On the contrary, the cruelty of loan sharks makes the poor worse off. The interest that borrowers lend to borrowers brings in injustice and harm.

In contrast to Islamic microfinance with a profit-sharing system that brings justice to all parties and benefits. Grameen Bank micro financing has a significant relationship with poverty alleviation because it is motivated by social justice side owned by micro finance. The side of social justice is shown by the target to be achieved is low-income society and micro business actors get the main priority. Financing for micro business actors is used to develop businesses and strengthen capital to compete with large traders (Nasim and Aman, 2009). According to Maria Nowak (2008), there needs to be a preferred opportunity equation with better access to factors of production and microfinance is part of that. Equality of opportunity and equality of mastery of the factors of production is what is strived by Islamic microfinance programs through the empowerment of the poor.

Contrary to that, J.U.J Onwumere (2012) from his hypothesis that microcredit in the Nigerian economy does not really help in poverty alleviation, but what happens is an increase in human capital. This means that microcredit in Nigeria has a nonsignificant impact on poverty alleviation and has a significant (positive) impact on human capital development. Agreeing with Onwumere, Anis Chowdhury (2009) states that microfinance develops some business strategies and impacts on poverty reduction is still in doubt. Because, microfinance is only one aspect of the many support needed by micro-enterprises. Other aspects needed are training, skills, and access to marketing 
information. Dan Matovu (2006) also expressed doubts about the role of microfinance for poverty alleviation. According to him, poverty alleviation by microfinance is like a drop of water in the ocean, very small. He added that microfinance knows only about the symptoms of poverty, not the real cause of poverty and which is not well developed up to now is the empowerment of women with the help of microfinance. Meanwhile Katsushi S. Imai (2010) stated that some evidence creates black spots on microfinance. Much microfinance research has been shown to have a negative impact on women's empowerment. If women do not have the same portion as men to get microfinance facilities, then society cannot control poverty.

\subsection{Relationship level capability of members of Mitra Dhuafa coop- erative with poverty alleviation}

Poverty is identified as a condition of capabilities deprivation, ie the loss of something that is intrinsically very important because it results in the diminishing ability of a person to give value to his life with their "doings" and "beings" (Kemal Azis Stamboel (2012). Therefore, capability is one of the variables that need to be included in this study because the capability approach emphasizes the multidimensional nature of analysing poverty problems This approach has broader powers than poverty measured only by the size of income or income poverty (Rod Hick, 2012) The relationship of capability level of members of Mitra Dhuafa Cooperative with poverty alleviation can be known by looking at Spearman correlation test result in the following Table:

TABLE 5: SPEARMAN TEST RESULTS VARIABLE LEVEL CAPABILITY OF MEMBERS WITH VARIABLE POVERTY ALLEVIATION.

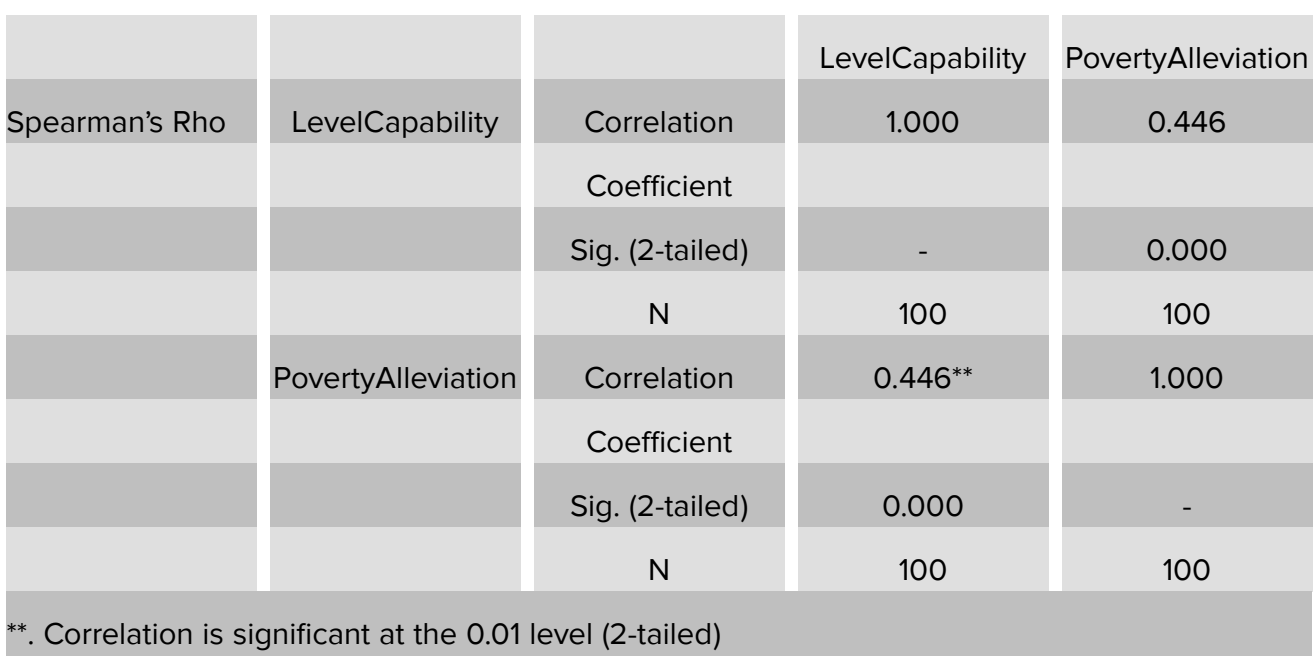

Based on Spearman test results table above, can be seen the correlation value of 0.446 . This means that there is a relationship between the level of member capability 
and poverty alleviation. Positive relationship of member cooperative capability level to poverty alleviation cannot be separated from micro financing service. Because of microfinancing, members of cooperatives have more opportunities, opportunities and options to seek to improve the welfare of life. Opportunities, opportunities, and options can enhance capability, which capability plays an important role in determining a person's level of well-being. Thus, the poor must be empowered to become capable human beings, and can get out of the poverty trap.

The opportunity given by Mitra Dhuafa Cooperative is opening and developing micro business. Since the poor live in the countryside, the businesses that are run not only trade, but also farming and rising. Revenues from these various businesses strengthen the family members' economy, so they can make valuable choices for their lives. These options include the option of funding their children's schools to college, the option of healthy living, and the option to meet the family's nutritional needs by serving nutritious foods.

Education and health are two of the most basic things that everyone must meet. Both are also the right of the poor to obtain it. If that cannot be achieved by the poor, then their basic ability has been seized. This is consistent with what was written by Rod Hick (2012) on Amartya Sen's thinking that the perspective of capability sees poverty as a deprivation of basic ability. Like physical appropriation is the adequacy of nutrition.

The relationship between the level of capability and poverty alleviation can be seen from the significance value in Table 5 above. Based on the table, the significance value is 0.000 . Thus, the significance level of 0.000 is smaller than the alpha of $5 \%$ or $0.000<0.05$. So it can be concluded that the level of member capability does have a significant relationship to poverty alleviation. This reinforces Kemal Azis Stamboel's (2012) assertion that the higher the basic capability is the higher the chance to increase its potential. In line with Kemal Azis Stamboel, Gunawan Sumodiningrat (2009) said that the more ability possessed, the greater his freedom to determine the choice of value for the welfare of a person.

Statement Kemal Azis Stamboel (2012) and Sumodiningrat (2009) means that the capability of a person affect the level of welfare. It also means that the higher the capability or ability of a person, the higher the poverty rate will decrease. Therefore, the endeavour to end this multidimensional poverty is to provide equal opportunities and opportunities for the poor to access services (capital, health, education) and factors of production. Those who cannot access the factors of production are not capable or powerless. Thus, the struggle to alleviate poverty begins with the empowerment of the poor. 
The significant relationship between the level of capability of cooperative members and poverty alleviation cannot be separated from the role of Mitra Dhuafa Cooperative. The cooperative has tried to provide opportunities and options to poor mothers to get micro financing because mothers play a big role in the development and future of their children. The cooperative also invites poor women who are members to apply for an education funding loan and this is for the future of the children of the poor.

This is a process of human development in order to become capable human, so have a high level of capability. Felton Earls, a professor at Harvard University stated that the core of Amartya Sen's capability theory is that every society has a responsibility to develop programs for every citizen, especially children, so that they can achieve maximum fulfillment and develop into capable human beings. It emphasizes that human development is essential to creating capable human beings, so that they are able to choose good decisions for their lives, by doing something (doings) or into something (beings). In this case, Mitra Dhuafa Cooperative has tried to help poor women to become capable human beings (Irwan, 2007).

\subsection{The role of islamic microfinance and capability level of cooperative members on poverty reduction}

Microfinance has a relationship with poverty alleviation, with a correlation value of 0.268 . While the level of member cooperative capability has a relationship with poverty alleviation, with a correlation value of 0.446 . Thus, the relationship possessed by the level of cooperative member capability (value: 0.446 and significance 0.007) with poverty alleviation is greater than the relationship of micro finance (value: 0.268 and significance 0.000 ) with poverty alleviation. Microfinance and capability level of cooperative members have a significant relationship to poverty alleviation. This means that if the utilization of micro financing is better and the level of cooperative member's capability is higher, then the chances of success in poverty alleviation will be greater. Microfinance is an instrument of empowerment, a tool for giving opportunities and options to the poor so that they can become independent and capable human beings. Being a capable human being, enabling him to have a higher level of welfare. Capacity is the basic ability of every human being. Thus, the cause of poverty measured in the space of ability is reduced or loss of one's capability. Therefore, to alleviate the poor from poverty is to increase their capability so that they can help themselves and not fall into poverty. This is in accordance with the statement of Abu Huraerah (2008), which reveals several strategies that must be done to overcome poverty, among others by increasing 
the ability and encourage productivity. The strategy to be chosen is to increase the basic capabilities of the poor to increase income through improved access to health and education services, business skills improvement, technology literacy, networking and market information.

The degree of capability is the basic ability of the poor to "doings" and "beings". It is natural that the level of capability is stronger in affecting one's well-being compared to other variables (micro-financing), because it is directly related to the choices of life. People, who cannot afford to "doings" and "beings", certainly cannot have the options to live a more prosperous life. However, microfinance positions still have an important role in the process of poverty alleviation. Therefore, access to microfinance with Grameen Bank pattern has a dimension of social justice and alignment to the poor and marginalized. This is evidenced by the micro financing system in Mitra Dhuafa Cooperative siding with the poor; without collateral, using a joint responsibility system, social capital transfer, business monitoring, and special attention to the children of cooperative member mothers with the form of providing education funding and employment opportunities for such children at Mitra Dhuafa Cooperative Institution. Wiloejo Wirjo Wijono (2005) confirmed that loans in the form of capital for micro-enterprises are one of the most powerful efforts in dealing with poverty. This is based on the fact that there are differences in classification which include: (1) the extreme poor, i.e. those who are not income and do not have productive activities, (2) the community in the poor category, but have the productive activities (economically active working poor), (3) lower income, those who have income, but only slightly. The approach used in poverty alleviation for the first poor will be more appropriate if direct approaches are used, such as food and subsidy programs. As for the second and third poor groups, more effective use of indirect approaches such as creating a climate conducive to the progress of micro enterprises and the development of various types of micro loans for SMEs.

Based on the classification of Wiloejo Wirjo Wijono (2005) on the poor group above, the economic empowerment conducted by Mitra Dhuafa Cooperative through micro financing is in the classification of economically active working poor and lower income. The Mitra Dhuafa Cooperative provides loans to poor women not for free or no obligation to return. To that end, each member or family of the member concerned must have a micro business, whether in agriculture, livestock, or commerce. However, although they have businesses, they are still in the poor category (economically active working poor) because all basic needs have not been met (including education and health). In addition, most of them are still low income (lower income). 
In the opinion of Wiloejo Wirjo Wijono (2005) above, microfinance is unsuitable for those who are very poor, arguing that they need immediate assistance. However, Mitra Dhuafa Cooperative with Grameen Bank pattern is not the case. Microfinance from cooperatives reaches all the poor, even very poor people. Khaled and Farhana (2011), quoting Muhammad Yunus's statement that the more a person is in a state of deprivation, the more interesting (to Grameen Bank). If a person has absolutely nothing, then he will get the highest priority (from Grameen Bank). Top priority is given to poor people who do not own land and other valuable assets, have no fixed income, and people who are in vulnerable condition.

\subsubsection{Relation of women with poverty level}

Rural poverty reduction is more effective through empowerment. The purpose of empowerment to create independence of rural communities, so that they are not dependent on family compassion, relatives, and government assistance. The profession of rural communities is engaged in agriculture and trade (micro and small enterprises). Both are real sectors that have been supporting the national economy. Susi Ratnawati (2011), states that poor women in rural areas are generally very closed, requires patience and a personal approach through the formation of small groups that are conducted intensely and informally.

Powerlessness is the cause of poverty in the village. This condition arises from lack of employment, isolation, low levels of education, lack of expertise and lack of access to business capital, causing them to become poor (Muhammad, 2011). Therefore, the solution to end poverty in them is by empowerment. Empowerment requires the participation of the poor in development programs. Thus, the poor must be made able to participate more. The lack of participation in development programs is experienced by women. The analysis of poverty and gender represent two interrelated centres of problems in the planning of development programs. Women's important role in developing country development has gained recognition (Nina, 2009).

Rani Andriani Budi Kusumo (2008), states that the involvement of wives in decisionmaking in domestic work and in the public sector has a correlation with the level of family welfare, especially farm families. Women are generally still weak in access to capital, land and agricultural production facilities. This situation is often the reason that women's productivity is lower than men. Therefore, women should be involved in various counselling, training, and other empowerment programs. The goal is for women to participate actively in development. 
Mitra Dhuafa cooperatives use Grameen Bank pattern, which is by personal approach and forming small groups in providing micro finance to poor women in rural areas. This approach is beneficial for poor women so that at the time of group gathering, they freely devote all problems, wishes, and hopes and discuss with fellow women in order to realize a more prosperous family. Muhammad Yunus and Karl Weber (2011), argue that women are important to be empowered because microfinance given to them will bring more benefits than men and the benefits are directly felt by children. In addition, women have a stronger push to end poverty in their families.

Tazul Islam (2007) added that women who earn or have their own wages tend to spend their income on something more beneficial for the household. Women are more proportional in spending their extra income on something that can increase human capital development, such as cooking more nutritious and nutritious food for families, better healthcare, education for children, and better sanitation. In addition, "when women earn, children learn". When women have income, children will be able to learn (school). Women have a strong desire to escape poverty. Unfortunately, poor women do not get the training and use of appropriate technology to make them more productive.

In line with Muhammad Yunus and Tazul Islam, Susi Ratnawati (2011) writes several things that are the main factors why empowerment for women must be done, namely: (1) women have the same interests in development and also the user of development result, equal rights with men, (2) women also have special interests for women themselves and children. Which interests are less optimal if initiated by men because it requires a special sensitivity, related to everyday, and socio-cultural, (3) empowering and involving women in development, it will also empower and transmit a positive spirit to next generation. Because, children in general in everyday life very close and attached to the Figure of a mother.

\subsubsection{Age of women and poverty level}

Mitra Dhuafa Cooperative in channeling micro finance does not discriminate the age of members. Therefore, poverty does not know the age and can happen to anyone. Although in the age class there are levels of age in which is usually called the productive age. In this study, the youngest respondent was 19 years old and already had children. While the oldest respondent aged 79 years and still strong work. In rural areas, the poor do not know the age because everyone has to work to survive, even though they are 
not in the productive age anymore. Description of respondent's age can be seen in the following Table:

TABLE 6: Range of Members Age of Cooperatives.

\begin{tabular}{|l|c|c|c|c|}
\hline No & Range of Age & Frequency & Percentage & Average Score \\
\hline 1 & $\leq 30$ years & 28 & $28 \%$ & 57.61 \\
\hline 2 & $31-50$ years & 48 & $48 \%$ & 58.46 \\
\hline 3 & $51-70$ years & 18 & $18 \%$ & 57.50 \\
\hline 4 & $\geq 71$ years & 6 & $6 \%$ & 59.50 \\
\hline
\end{tabular}

Based on Table 6, respondents were aged between 31-50 years, 48\% (48 persons) and followed by age less than 30 years (=30 years), 28\% (28 persons). This means that respondents are dominated by cooperative members who have productive ages. According to Gunawan Sumodiningrat (2009), the target that focuses on poverty alleviation through empowerment strategy is productive poor people, ranging from 15 years to 55 years. Poor people in this age range, generally healthy physically and spiritually are human resources that have great potential to become active actors in development.

Arya Dwiandana and Nyoman Djinar (2013) stated that age is one of the factors affecting one's income. According to him, productive age ranges between 15-64 years which is the ideal age for workers. In the productive period, in general the more aged the income will increase, which depends also on the type of work done. Physical strength of a person to do the activity is closely related to age, because if a person's age has passed the productive period, then the decreased physical strength so that productivity is decreased and income also comes down. Although in this study the definition of poverty is not only focused on income poverty, but income is one dimension that exist in the problem of multidimensional poverty.

In line with Arya Dwiandana and Nyoman Djinar, Rani Andriani (2008), confirmed that adequate wife's age can support productive activities, making wives as extra breadwinners to meet family needs. Furthermore, to prove whether there is a difference in poverty rate with the age range of members, it can be seen from the results of KruskalWallis test in the following Table:

Based on the above Table, obtained Chi-Square value count for 0.983 . While the value of Chi-Square table for $\mathrm{df}=3(4-1)$ and alpha $5 \%$ is 7.8147 . This means that ChiSquare count is smaller than the Chi-Square table or $0.983<7.8147$. Thus, it can be concluded that the poverty rate in the age range of members of different cooperatives 
TABLE 7: Results of Kruskal-Wallis Test Differences in Age Range of Cooperative Members with Poverty Level.

\begin{tabular}{|c|c|}
\hline \multicolumn{2}{|c|}{ Test Statistics ${ }^{a, b}$} \\
\hline & Poverty \\
\hline Chi-Square & 0.983 \\
\hline Df & 3 \\
\hline Asymp. Sig. & 0.805 \\
\hline \multicolumn{2}{|c|}{ a. Kruskal Wallis Test } \\
\hline
\end{tabular}

is no different. The result of Kruskal-Wallis test shows the number of Asymp. Sig. of 0.805. This figure is much greater than 0.05 which means that the age range does not have a significant difference with the poverty level. It can be said that there is no difference in the poverty rate at the age of different respondents, from the youngest age 19 years to the age of 79 years old. Age differences, young or old do not determine a person poorer or more prosperous.

The productive age range generally ranges from 15 years to 55 years, but it turns out that the age of cooperative members does not significantly affect the level of poverty they experience. Poverty in rural communities is generally a legacy of parents. They since childhood did not get access to proper education and health because their parents did not have the ability to access them. Until the big children, poverty remains inherited because it has no natural capital, financial capital, and social capital to improve the quality of life and family welfare. It could be those who are younger, have a chance to be more prosperous because they have opportunities and opportunities wider than the older ones. However, it is undeniable that older people also have more prosperous possibilities because they have more expertise and experience in working. Thus, both young and old have basically the same options and opportunities to improve their wellbeing. Who seriously strives to rise from poverty, then he are the one who welfare? Therefore, Partner Cooperation Dhuafa does not discriminate the age of prospective members to get a loan. The cooperative trusts all members to use microfinance to open and develop micro businesses.

Based on the above rank rank, the mean rank of the highest poverty rate was achieved at the age between 71-80 years and the lowest was reached at the age between 51-70 years. Cooperative members who are in the age range are no longer productive, have a mean rank is high enough. However, based on the Kruskal-Wallis test it concluded that there was no difference in poverty rates across various age ranges of members of the Mitra Dhuafa Cooperative. This is not in accordance with the statement of Arya 
TABLE 8: OUTPUT RANK POVERTY RATE BASED ON AGE RANGE MEMBERS OF MITRA DHUAFA COOPERATIVES.

\begin{tabular}{|l|c|c|c|}
\hline \multicolumn{1}{|c|}{ Ages } & N & Mean Rank \\
\hline Poverty & 20-30 years & 28 & 48.04 \\
\hline 31-50 years & 48 & 52.38 \\
\hline $51-70$ years & 18 & 47.08 \\
\hline $71-80$ years & 6 & 57.25 \\
\hline & Total & 100 & \\
\hline
\end{tabular}

Dwiandana and Nyoman Djinar (2013), which states that age is a variable that has a dominant influence on the income of poor households.

Poverty in Arya Dwiandana and Nyoman Djinar (2013) research is defined as income poverty, or poverty measured only from high household income. While in this study, poverty is measured from various dimensions, because in fact poverty is a multidimensional problem that is not only concerned with money. Radhitya Widyasworo (2014) wrote the opinion of Amartya Sen, that the problem of poverty is not just a matter of income alone. Poverty is related to the capabilities that must be possessed by everyone, one of them concerning access to education, health, and employment opportunities. Thus, the handling of poverty will be more comprehensive.

\subsubsection{Women's profession and poverty level}

The main requirement of Mitra Dhuafa Cooperative in providing micro financing to its members is the obligation to use the loan for micro, productive, and real sectors. The cooperative does not specify the type of business undertaken by its members. Each member has different potentials and gifts. Therefore, each member is free to choose what type of business will be run and developed. For poor households, the dual role of women in the household is a necessity to help improve the household economy (Radhitya Widyasworo, 2014).

Women's role as a household economic asset becomes very important because of their inner and sacrificial ethos, they work to survive or at least for the sake of their children, albeit with very minimal incomes and insufficient infrastructure supporting their existence. Therefore, the support and opportunity for poor women to empower themselves and improve their welfare becomes very strategic (Khusnul, 2009). With regard to their environment in the countryside, the types of businesses selected by members of the majority cooperative are traders and farmers. Although there are also 
claiming to be housewives. Cooperatives allow micro businesses to be run by other family members. If the business is run by other family members, then the mother automatically works as a housewife. However, the mother remains fully responsible for family finances, regularly paying weekly instalments, and diligently saving. This happens to many young mothers who still have children aged fewer than five, so cannot work outside the home. In fact, when the weekly gathering, the children are invited and they confess that her husband is running a micro business. Types of professions run by members of cooperatives can be seen in the following Table:

TABLE 9: TYPE OF COOPERATIVE MEMBER PROFESSION.

\begin{tabular}{|c|c|c|c|c|}
\hline No & Profession & Frequency & Percentage & Average Score \\
\hline 1 & Merchants & 40 & $40 \%$ & 58.20 \\
\hline 2 & Farmers & 47 & $47 \%$ & 58.91 \\
\hline 3 & Housewife & 13 & $13 \%$ & 54.92 \\
\hline
\end{tabular}

Based on the Table 9, it is known that the most profession run by members of the cooperative is farmers, as many as 47 people or $47 \%$. The second largest profession and the amount is almost the same as the farmer is the profession of traders, as many as 40 people or $40 \%$. The smallest type of profession is housewife as many as 13 people or $13 \%$. The highest average welfare score is in the farming profession (58.91) and the trader (58.20). Although the average score of each profession is different, the type of profession may not necessarily affect the level of welfare and poverty levels experienced by each member. Furthermore, to prove whether there are differences in poverty levels in the three types of cooperative member professions, can be seen from the results Kruskal -Wallis test in the following table:

TABLE 10: RESULTS OF KRUSKAL-WALLIS TEST DIFFERENCES IN POVERTY LEVELS IN THREE TYPES OF PROFESSIONAL MEMBERS OF MITRA DHUAFA COOPERATIVES.

\begin{tabular}{l}
\multicolumn{2}{c}{ TEST STATISTICS $^{a, b}$} \\
$\begin{array}{lc}\text { Kemiskinan } \\
\text { Chi-Square } & 4.585 \\
\text { Df } & 2 \\
\text { Asymp. Sig. } & 0.101 \\
\text { a. Kruskal Wallis Test } & \\
\text { b. Grouping Variable: Profession }\end{array}$
\end{tabular}


Based on the results table Kruskal-Wallis test, obtained Chi Square count value of 4.585. While the value of Chi-Square table for $\mathrm{df}=2(3-1)$ is 5.9915 . Thus, the calculated Chi-Square value is smaller than the value of Chi-Square table or $4.585<5.9915$. This means that there is no difference in poverty level with the type of cooperative member profession. So any kind of profession, all have the same opportunity to get out of poverty and equal opportunity to achieve prosperity. Therefore, regardless of the type of professionally in carrying out his responsibilities, then he will be able to get out of the poverty that binds him. Furthermore, the significance value is 0.101 and this value is greater than alpha $5 \%$ or $0.101>0.05$. Thus, it can be concluded that the type of profession does not cause a significant difference to the poverty of members of the cooperative. Thus, any kind of profession can be a way to achieve empowerment and independence. Each profession can achieve the same goal, i.e. ending poverty, if human resources have a high degree of capability.

Providing microfinance by Mitra Dhuafa Cooperative is an effort to give opportunity for the poor to be independent, so they have high capability. The level of capability is demonstrated by being a successful farmer producing high quality agricultural products and having a high selling price. So also with a trader, he is able to maintain the quality of merchandise and able to meet market demand.

TABLE 11: OUTPUT RANK DIFFERENCE POVERTY RATE IN PROFESSIONAL TYPE OF MITRA DHUAFA COOPERATIVE MEMBER.

\begin{tabular}{|l|c|c|c|}
\hline & Profession & N & Mean Rank \\
\hline Poverty & Merchants & 40 & 50.93 \\
\hline & Farmers & 47 & 54.41 \\
\hline Housewife & 13 & 35.4 \\
\hline & Total & 100 & \\
\hline
\end{tabular}

Table 11 shows that the mean rank of the highest poverty level is in the farming profession. While the lowest mean rank in the profession of housewives. They do not work outside the home because they still have toddlers and micro-finance used by trusted family members. Although the results of the Kruskal-Wallis test show that there is no difference in poverty levels with different types of professions that are lived, but actually farmers have a larger asset in the form of agricultural land. Because, farmers here are not farmers. For poor people who do not have fields, they choose to open small businesses such as herbal trades, fish, fruits, or vegetables.

Farmers in remote villages are still many who have their own land, not rent. However, it is undeniable that their welfare is not guaranteed. Especially if the size of welfare 
is only seen from the high low income only. Of course many farmers are included in the category of income poverty. Ironically, farmers are the most profitable profession in producing food and meeting the basic needs of the national so that the upper middle class does not starve, but, it is the families of farmers who suffer from hunger and poverty.

Mitra Dhuafa cooperatives have been working to improve their welfare by lending financial capital and providing social capital. Governments and policy holders must also contribute to their welfare. According to Dewa Ketut Sadra Swastika (2013), various strategic steps can be taken to release farmers from the poverty trap. These strategic measures include: (1) increasing land tenure through the realization of an enduring 15 million ha of agricultural land, (2) increasing productivity through the application of advanced technology, (3) opening up access to vast capital sources for farmers, (4) consolidate smallholder management of small-scale enterprises into corporate farmers to improve farmers' bargaining position; (5) establish business partnerships between farmers and agricultural industry entrepreneurs to ensure the availability of production facilities and marketing of primary food products; and (6) provide protection to farmers in the form of production input subsidies and purchasing price policies by the government.

\subsubsection{Duration of membership and poverty level}

Mitra Dhuafa Cooperative does not make limits on how long a person should be a member. Each member is given the freedom to decide how long he or she should be part of the cooperative. In general, those who have felt able to stand on their own and the well-being of their families have increased, so by themselves they are breaking away. However, every year the cooperative continues to evaluate and evaluate to each member about the achievements that have been achieved. Because the ability and potential possessed by each member is different, the duration of membership also varies. In this study there are four kinds of membership duration, namely:

Based on Table 12, members of the cooperative who became the respondents most have membership duration for 3 years, i.e. 44 people or $44 \%$. The second and third largest percentages are members with membership duration of 1 year and 2 years. $22 \%$ and $21 \%$ respectively. While the number of members who have membership duration for 4 years is 13 people (13\%). The longer the membership duration is not guaranteed to have the highest average score. Looking at the average scores in the table above, the highest average welfare score score is that has membership duration of 2 years. 
TABLE 12: MEMBERSHIP DURATION OF COOPERATIVES.

\begin{tabular}{|c|c|c|c|c|}
\hline No & $\begin{array}{c}\text { Membership } \\
\text { Duration }\end{array}$ & Frequency & Percentage & Average Score \\
\hline 1 & 1 year & 22 & $22 \%$ & 53.68 \\
\hline 2 & 2 year & 21 & $21 \%$ & 60.52 \\
\hline 3 & 3 year & 44 & $44 \%$ & 59.49 \\
\hline 4 & 4 year & 13 & $13 \%$ & 57.31 \\
\hline
\end{tabular}

In this case, when the level of welfare rises then of course the poverty rate decreases. Furthermore, it is necessary to test and analyse whether there is a difference in poverty alleviation rates in the duration of women's membership. To know this, can be seen from the results Kruskal-Wallis test in the following Table:

TABLE 13: KRUSKAL-WALLIS TEST RESULTS DIFFERENCES IN POVERTY LEVELS IN MEMBERSHIP DURATION.

\begin{tabular}{|c|c|}
\hline \multicolumn{2}{|c|}{ TEST STATISTICS ${ }^{a, b}$} \\
\hline & Poverty \\
\hline Chi-Square & 17.723 \\
\hline Df & 3 \\
\hline Asymp. Sig. & 0.001 \\
\hline \multicolumn{2}{|c|}{ a. Kruskal Wallis Test } \\
\hline
\end{tabular}

Based on the results table Kruskal-Wallis test, obtained Chi Square count value of 17.723. While the value of Chi-Square Table for $d f=3(4-1)$ is 7.8147. Thus, the ChiSquare value count is greater than the $F$ table value, or $17.723>7.8147$. Thus, it can be concluded that there are differences in the level of poverty alleviation with the duration of membership. This conclusion is strengthened by looking at the significance value. The significance value obtained in the Kruskal-Wallis test results table is 0.001 and this is smaller than the $5 \%$ alpha, or $0.001<0.05$.

Thus, it can be concluded that poverty alleviation rates have significant differences in membership duration. Hypothetically simple, for women who have been longer members of the cooperative will be more prosperous than those who just joined the members. Because, for the longer members, they have gained a lot of material and moral support from cooperative institutions. Therefore, for those who have had more than one year membership duration, they should have strengthened financial capital 
and social capital. According to Sri Edi Swasono (2010), the evidence for a successful empowerment is if there is self-empowerment in the people as a form of increased economic value added (productivity) and added value of socio-cultural (dignity) in the people. Not the other way around, people marginalized from economic opportunities and pushed them to fall into the attitude of self disempowerment, attitude, apathy and paralysis.

In line with the length of membership duration, it is necessary to fulfill the necessities of life and increase self-sufficiency has been achieved. According to Tiktik Sartika Partomo (2013), cooperative membership is voluntary and open. Therefore, as long as it has the same interests and objectives, it can be served by the cooperative without discrimination. If the strengthening of economic capital, social capital, and human capital has been achieved, then it would be good to avoid the emergence of dependence, concerned stop applying for Islamic microfinance so that the funds can be re-rotated to other parties more in need. However, for the prosperous, the consequence is that there must be a personal willingness to strengthen relationships with cooperative institutions and with groups still struggling to achieve independence and prosperity.

Furthermore to know rank of poverty alleviation member of cooperative based on membership duration can be seen in Table 14 below:

TABLE 14: OUTPUT RANK OF POVERTY ALLEVIATION LEVEL BASED ON MEMBERSHIP DURATION.

\begin{tabular}{|c|c|c|c|}
\hline Profession & N & Mean Rank \\
\hline Poverty & 1 year & 22 & 29.43 \\
\hline 2 year & 21 & 62.29 \\
\hline 3 year & 44 & 56.91 \\
\hline 4 year & 13 & 45.42 \\
\hline Total & 100 & \\
\hline Source:Data research results & & \\
\hline
\end{tabular}

Table 14 shows that the mean rank of the highest level of poverty alleviation is achieved by members of the cooperative having membership duration of 2 years. The lowest mean rank on 1-year membership duration. While members, who have membership duration of more than 2 years, experienced a downward trend average score. This means that if you become a member of the cooperative and use microfinancing for only 1 year, then the results obtained are not maximized. However, if the membership duration exceeds two years or too long, then the results obtained are also not as maximal when in position 2 years. 
This reinforces the results of M. Jahangir Alam Chowdhury (2008) study, which assesses the impact of micro-loans on household poverty levels in Bangladesh and the Philippines. Chowdhury states that household poverty rates are declining in line with increasing membership duration in micro-lending programs. M. Jahangir Alam Chowdhury also concluded that there is a positive relationship between the duration of membership and the number of micro loans to poverty levels in both countries.

In Bangladesh, the poverty reduction capacity of microfinance programs declined after a sixty month membership duration. This means that after poor people become members and get microcredit for 5 years, the role of micro loans for poverty alleviation is reduced. While in the Philippines, there is a downward trend of poverty rates due to participation in microfinance programs, more slowly until the loan amount is more than P20,000. It should be longer a person becomes a member then the higher the level of poverty alleviation is achieved. In other words, the higher the welfare of the member. One of the factors that can be asked to analyse this is dependency. That is, at its peak, the second year of membership, the poor women had a very high mean rank. They have the opportunity and support to end poverty with microfinance, business monitoring, and social capital provided routinely by the Mitra Dhuafa Cooperative.

Entering the following year members are feared trapped in dependence, which is a cooperative helping hand. The hope is that dependence does not really happen as happened in government poverty alleviation programs. According Kemal Azis Stamboel (2012), poverty alleviation programs undertaken by the government is a good program, but not enough to alleviate poverty to the root. Programs that have been implemented are very helpful in increasing the purchasing power of the poor to meet basic needs. On the other hand, these programs create a condition of dependency among the poor. When viewed objectively, the majority of poverty is multidimensional, caused by human resources, structural obstacles, institutional governance, and socio-cultural. So it requires the design of poverty alleviation policies that must be comprehensive. This is not without reason, because for those who are accustomed to the help and help of other people's hand is feared complacent with comfortable circumstances, so that the goal to achieve independence a little forgotten. The role of Cooperative Mitra Dhuafa to continue to monitor and direct them to the independence must be maintained. Periodic evaluations are important to do in order to know which members are self-reliant and have been able to help themselves to end poverty. If it is independent, then there is no harm to be released. As expressed by Maria Nowak (2008), that the salvation of the poor lies in their own efforts. Their salvation is not in the compassion and the helping hand of others. 


\section{Conclusion}

This research concluded that Islamic microfinance using Grameen model has a positive contribution to economic empowerment for poor women and poverty alleviation in the countryside. The success of empowerment can be reached by strengthening financial and social capitals for poor women. Social capital becomes the guaranteeing factor for the continuity of empowerment program using Grameen system. Characteristics of successful empowerment of poor women are the increasing number of women's weekly income and growing self-reliance in terms of food, health and education.

This study also proved that poverty can be overcome if economic development is done based on human development. Human development is done through empowerment. Financial capital and social capital are the keys to success in empowering the poor people. This is based on Spearman correlation test results which indicate that capability level (capability of human resources) of members of cooperatives have a significant relationship with poverty alleviation. The facts on the field show that microfinance using Grameen program is very helpful for poor women in empowering themselves. The findings in this study prove that $66 \%$ of respondents admitted that microfinance programs ease the financial burden on their families and $28 \%$ claimed to be sometimes helped by microfinance programs. Another impact is the growing saving culture among the poor. As many as $50 \%$ of respondents always regularly save their money weekly to cooperatives and the remaining $48 \%$ do as well but more rarely. While the non-financial contributions earned by the poor women as members of the cooperative are in the forms of independence, discipline, courage, responsibility, confidence, and increased bargaining power. Another contribution, which is a crucial role in poverty alleviation, is to improve the poor's capability. Amartya Sen (1981) stated that to overcome poverty, human development must be put on top of economic development. Cooperative 'Mitra Dhuafa' provides opportunities, chances, and trust for poor women to strive for prosperity. The cooperative seeks to improve the poor's capability by humanizing humans and breaking dependency. The rural poor are marginalized and excluded. Thus, giving them access to venture capital is very valuable.

This study reinforced the results of research by Shah Shirazi and Ullah Khan (2009) which concluded that microfinance in Pakistan had reduced the national poverty rate by $3.07 \%$. This also supported the statements of Kumar Shastri (2009), Muhammad Yunus (2008), Alam Chowdhury (2008), Anwarul Kabir (2012), Khan Durrani (2011), Musa bin Mansour and Tawfiq Brahm Chaouch (2013) who proved that microfinance created self-employment opportunities which have impact on poverty alleviation and 
unemployment. This study also strengthened the opinion expressed by Amartya Sen (1981), Apsan Frediani (2007) and Ingrid Robeyns (2003) which stated that the level of capability (basic ability) of a person was in correlation with the level of poverty he/she experienced. Meanwhile, this study differed from the conclusions shown by Onwumere (2012) and Matovu (2006) which suggested that Microfinance in Nigeria had an insignificant impact on poverty alleviation. This study also did not match the research results of Anis Chowdhury (2009) which stated that Microfinance created black spots, because women do not have the same portion as men, so that people cannot control poverty.

\section{Acknowledgment}

The authors would like to thank LPDP for providing the research grant, Graduate School State Islamic University of Syarif Hidayatullah Jakarta, and Islamic Economic and Business Faculty, Universitas Suryakancana for supporting in this research.

\section{References}

[1] Abur, C.C. \& Torruam, J.T. (2012). Microcredit as a strategy for poverty reduction in makurdi local government area of benue state, Nigeria. International Journal of Humanities and Social Science, 2(12), 179-186.

[2] Amalia, E. (2009). Keadilan Distributif dalam Ekonomi Islam: Penguatan Peran LKM dan UKM di Indonesia. Raja Grafindo Persada, Jakarta.

[3] Bakhtiari, S. (2006). Microfinance and poverty reducing: Some international evidence. International Business and Economic Research Journal. 5(21), 65-71.

[4] Chapra, U. (2000). The Future of Economics: An Islamic Perspective. The Islamic Foundations. Leicester.

[5] Chapra, U. (1985). Towards a Just Monetary System, The Islamic Foundation, London.

[6] Chowdhury, A. (2009). Microfinance as a poverty reduction tool: A Critical Assessment. Working Paper, department of economic and social affairs (Desa).

[7] Chowdhury, M.J.A. (2008). Poverty and Microfinance: An investigation into the role of microcredit in reducing the poverty level of borrowing households in bangladesh and the Philippines. The Whitehead Journal of Diplomacy and International Relations, 9(2), 19-35.

[8] Durrani, M.K.K. (2011). Role of microfinance in reducing poverty: A look at social and economic factors. International Journal of Business and Social Science, 2(21), 
$138-144$

[9] Gera, N. (2009). Book review: Muhammad yunus with alan jolis, banker to the poor, the story of grameen bank. The Lahore Journal of Economics, 14(1), 173-175.

[10] Guilford. J.P. (1956). Fundamental Statistic in Psychology and Education, McGraw-Hill Book Company, New York.

[11] Hick, R. (2012). The capability approach: Insights for a new poverty focus. Journal of Social Policy. 41(2), 291-308.

[12] Huraerah, A. (2008). Pengorganisasian dan Pengembangan Masyarakat; Model dan Strategi Pembangunan Berbasis Kerakyatan, Humaniora, Bandung.

[13] Imai, K.S. (2010). Microfiance and poverty: A macro perspective. Unpublished manuscript, research institute for economic and business administration kobe, University Japan.

[14] Islam, T. (2007). Microcredit and Poverty Alleviation, Ashgate Publishing Limited, England.

[15] Julianto, I. (2008). Amartya sen dan nobel bagi kaum papa esai-esai nobel ekonomi. Kompas media nusantara, Jakarta.

[16] Kabir, M.A. (2012). The role of microcredit and microfinance institutions (MFIs): Extent and intensity of poverty, poverty alleviation and outreach. International Affairs and Global Strategy, 4(2), 29-47.

[17] Kaplan. R.M. \& Saccuzzo, D.P. (1993). Psychological testing principles, Application and issues, Brooks/Cole Publishing Company, California.

[18] Khotimah, K. (2009). Diskriminasi gender terhadap perempuan dalam sektor pekerjaan. Jurnal YINYANG: Studi Gender dan Anak, 4(1), 158-180.

[19] Kuncoro, M. (2013). Mudah Memahami dan Menganalisis Indikator Ekonomi, UPP STIM YKPN, Yogyakarta. Kusumo, R.A.B. Analisis Peran Gender Serta Hubungannya dengan Kesejahteraan Keluarga Petani Padi dan Hortikultura di Daerah Pinggiran Perkotaan. Jurnal Media Gizi dan Keluarga, 32(2),52-64.

[20] Matovu, Dan. (2006). Microfinance and poverty alleviation uganda, unpublished manuscript, master thesis africa and international development cooperation, goteborgs universitet.

[21] Mehta, C.R. \& Nitin, R.P. (2010). IBM SPSS Exact Tests, Cytel Software Corporation, Cambridge.

[22] Nowak, M. (2008). Revolusi Kredit Mikro: Dimana Pinjaman Bukan Hanya untuk yang Kaya, Dian Rakyat, Jakarta. 
[23] Onwumere, J.U.J. (2012). The impact of microcredit on poverty alleviation and human capital development: evidence from Nigeria. European Journal of Social Review, 28(3), 416-423.

[24] Partomo, T.S. (2013). Ekonomi Koperasi, Ghalia Indonesia, Bogor.

[25] Purwoto, A. (2007). Panduan Lab Statistik Inferensial, Grasindo, Jakarta.

[26] Putri, A.D. \& Setiawina, N.D. (2013). Pengaruh umur, pendidikan, pekerjaan terhadap pendapatan rumah tangga Miskin di Desa Bebandem. E-Jurnal Ekonomi Pembangunan Universitas Udayana, 2(4), 173-180.

[27] Rahman, R. \& Qiang, N. (2011). The synthesis of grameen bank microfinance approaches in bangladesh, International Journal of Economics and Finance, 3(6), 207-218.

[28] Ratnawati, S. (2011). Model pemberdayaan perempuan miskin perdesaan melalui pengembangan kewirausahaan. Jurnal Kewirausahaan, 5(2), 2-15.

[29] Ridjaluddin. F.N. (2007). Nuansa-Nuansa Ekonomi Islam, Sejahtera, Jakarta.

[30] Ridwan, M. (2011). Manajemen Baitul Maal wa Tamwil (BMT), UII Press, Yogyakarta.

[31] Rochaety, E. (2009). Metodologi Penelitian Bisnis dengan Aplikasi SPSS, Mitra Wacana Media, Jakarta.

[32] Santoso, S. (2012). Aplikasi SPSS pada Statistik Non Parametik, Elex Media Komputindo, Jakarta.

[33] Schreiner, M. (2003). A cost-effectiveness analysis of the grameen bank of Bangladesh. Development Policy Review, 21(3), 357-382.

[34] Sen, A. (1981). Poverty and famines: An essay on entitlement and deprivation. Oxford University Press, New York.

[35] Shastri, R.K. (2009). Microfinance and poverty reduction in india: A comparative study with asian countries. African Journal of Business Management, 3(4), 136-140.

[36] Shirazi, N.S. \& Aman, U.K. (2009). Role of pakistan poverty alleviation funds (PPAF) micro credit in poverty alleviation. Pakistan Economic and Social Review, 47(2), 215-228.

[37] Shukran, K. \& Rahman, F. (2011). "A grameen bank concept: microcredit and poverty alleviation program in Bangladesh. In International Conference on Emerging Trends in Computer and Image Processing (ICETCIP) in Bangkok, Thailand, 47-51.

[38] Singarimbun, M. \& Effendi, S. (2008). Metode Penelitian Survai, Pustaka LP3ES Indonesia, Jakarta.

[39] Stamboel, K.A. (2012). Panggilan Keberpihakan: Strategi Mengakhiri Kemiskinan di Indonesia. Gramedia Pustaka Utama, Jakarta. 
[40] Sumodiningrat, G. (2009). Mewujudkan Kesejahteraan Bangsa: Menanggulangi Kemiskinan dengan Prinsip Pemberdayaan Masyarakat, Elex Media Komputindo, Jakarta. Supranto, J. (2009). Statistik Teori dan Aplikasi, Erlangga, Jakarta.

[41] Swastika, D.K.S. (2011). Membangun kemandirian dan kedaulatan pangan untuk mengentaskan petani dari kemiskinan. Jurnal Pengembangan Inovasi Pertanian, 4(2), 103-117.

[42] Suyanto, B. (2001). kemiskinan dan pemberdayaan masyarakat miskin. Jurnal Masyarakat, Kebudayaan, dan Politik, 14(4), 25-42.

[43] Tanjung, H. \& Devi, A. (2013). Metodologi Penelitian Ekonomi Islam, Gramata Publishing, Jakarta.

[44] Widyasworo, R. (2014). Analisis Pengaruh Pendidikan, Kesehatan, dan Angkatan Kerja Wanita Terhadap Tingkat Kemiskinan di Kabupaten Gresik (Studi Kasus 20082012). Jurnal IImiah Mahasiswa Fakultas Ekonomi dan Bisnis Universitas Brawijaya, 2(1), 1-17.

[45] Wijono. \& Wiloejo, W. (2005). Pemberdayaan lembaga keuangan mikro sebagai salah satu pilar sistem keuangan nasional: Upaya konkrit memutus mata rantai kemiskinan. Jurnal Kajian Ekonomi dan Keuangan, 86-100. Yunus, M. \& Jolis. A. (2010). Banker to The Poor: The Story of The Grameen Bank, Aurum Press Ltd, London.

[46] Yunus, M. \& Weber, K. (2011). Building social business: The new kind of capitalism that serves humanity's most pressing needs, Public Affairs, New York.

[47] Yunus, M. (2011). Vision 2050: A poverty-free world. Social business a step toward creating a new global economic order. The Journal of Social Business: Social Business and New Economics Paradigm, 1(1), 7-23. 